\title{
Perceived Performance on Tutors during Process of Certification in Four Teacher Training Institutions in Durango
}

\author{
Diana María Espinosa Sánchez \\ Miguel Ángel Muñoz López \\ Edgar Jarib Castro Luna
}

\begin{abstract}
Higher Education Institutions ( $\mathrm{HEI})$ currently face a major issue: low levels of certification and thus the terminal efficiency. The present research emerged on the need to know what the perceived performance of tutors on postgraduate levels during the certification process in four teacher training institutions in the State of Durango. The research has a quantitative approach. This work is presented both as descriptive and explanatory. The methodology used is survey, which was used as a technique and an instrument. Variables were considered to building up 177 items, with an Alpha Cronbach reliability $=.93$. A total of 85 students were surveyed, who are the total of students on process to obtain the MA degree on Education in the four institutions where the research was conducted. These institutions also hold the Institutional Tutoring Program (ITP). Some common traits on tutors were found, which may strengthen or weaken the process of certification; also, some factors that make certification difficult.
\end{abstract}

Keywords: Tutoring, tutor, certification, teacher training institution, academic, development

Introduction:

The present research aims to identify the performance on tutors during the process of certification on postgraduate level in four teacher training institutions in the state of Durango.

From the main objective, three specific sub objectives were derived:

a) To describe the characterization of the participants in the research.

b) To identify the common key traits on tutors which Foster the process of certification.

c) To know the common traits on tutors which weaken the process of certification.

The institutions that participated were: Centro de Actualización del Magisterio, la Universidad Pedagógica de Durango, la Benemérita y Centenaria Escuela del Estado de Durango y la Escuela Normal Rural "J. Guadalupe Aguilera", It is imperative to state that these three institutions offer the MA degree by means of a thesis; besides, these institutions operate under the ITP.

First of all, this research is relevant because there is little research based on the tutors' performance and how this impacts on the process of students' certification in these teacher training institutions in Durango.

Secondly, this research underlines the awareness on the different problems which impact on the quality on these HEI which offer post graduate studies either in public or private. It also highlights the low levels in certification and thus the terminal efficiency. This research does not make emphasis on the terminal efficiency, but on the intentions of certification students have.

Thirdly, the results and final outcome this research found helps to identify the different factors that are either blocking or favoring the performance on tutors during the certification process.

Finally, based on these given factors which are blocking or fav oring the certification process, after the analysis, a proposal will be possible to suggest suiting the tutors in the three teacher training institutions in the state of Durango. 


\section{Postgraduate Tutoring}

Tutoring has a different approach from that in bachelor's degree. Postgraduate Tutoring emphasizes on the process oriented to the fundamentals, designing and execution of a research, in other words, on the generation of new knowledge (Martínez, Laguna, García, Vásquez \& Rodríguez, 2005).

A postgraduate tutor fosters the interaction with the one being tutored and highlights the importance of the problems and questions on his surroundings; research problem analysis is conceived as a process of questioning and strategies to build up the new knowledge, from the previous knowledge and the active participation of the student. This way, tutoring supports the approaching of real problems and allows the one being tutored be the responsible of his own learning. (Martinez et al., 2005).

\section{Current State of Knowledge}

Experience has shown that after completing their studies, many students do not graduate immediately, but they let years go by. Some do not complete the process of the thesis, leaving behind the research that once was started; consequenty, they do not go through the process to present their thesis and do not obtain the MA certification. Jaik, "states that the answers or approaches to the roots which originate the phenomenon are endless". (2013 p.40)

Postgraduate studies are on the rise bringing along several serious concerns to national level; among those are: quality, relevance and terminal efficiency. Terminal efficiency reflects the quality in education and it is an indicator to evaluate the functioning and goals reached by an educational institute.

Postgraduate studies in Mexico face a chronic problem related to terminal efficiency. Most recent data indicate these levels are around 30\% (Jaik, Guzmán \& Ortega, 2010) as cited in (Navarro M, Jaik A. \& Barraza A., 2010).

According to a recent research report at Centro de Actualización del Magisterio in Durango, students who graduated between 2016 and 2011 only $41 \%$ took tutoring. It is less than the half who concluded. These students where starting their thesis; 59\% of those graduate students did not attend therefore were not able to obtain their certification. (Espinosa, 2013).

García Herrera (s.f.) conducts a research named "terminal efficiency in postgraduate studies oriented to researching", and states that among the factor related to the terminal efficiency are the lack of research formation and the difference on programs and curricula. Kala (2003) and Piña and Pontón (1997) as cited in (Jaik, 2013) stated that some of the causes are: a) variety of subjects with a lack of expert tutor son the given subject; b) a scarcity of tradition to complete a thesis during the postgraduate studies. Similarly Lopez Villegas (cited in Sánchez and Arredondo, 2001) who conducted a research with the terminal efficiency concludes there is a direct relationship in the lack a systematized research work, cited in (Jaik, et al. 2013).

This research aims at identifying the performance of tutors during the certification process, so it turns out to be essential to creating new researchers; according to Cruz, Cruz Barriga \& Abreu-Hernández (2010) it is a great potential to revive knowledge, integrate collaborative networking, innovation and knowledge transfer. These authors suggest tutors do not have it easy, for they lack proper instrument to guide their performance; thus their performance is according to their beliefs and own criteria, lacking a continuous reflection as trainers.

It is stated that the richness and cultural capital they possess related to their academic staff in sciences humanities and arts, is manifested in the tutoring system.

Postgraduate tutor must fulfill the mission to training new generations, to train them to conduct relevant research, high quality research with a social commitment, which contributes to the solution to national problems and at the same time strengthen the educative system at all levels. (Martínez, Laguna, García, Vásquez, \& Rodríguez, 2005).

\section{Methodological Design}

The research was conducted with a qualitative approach, this study is both descriptive and explanatory. The methodology used is the survey. A questionnaire was used as the technique and an instrument. It is build up to have 8 complex variables, which derived up to 158 simple variables to measure the trend with values from 0 to 10 where 0 is the lack of value and the 
10 is the highest value to a given question. There are a total of 177 items, nominal variables are 19 and they allow to demonstrate the characteristics of the subjects who were studied.

The questionnaire was revised under these three aspects: content validity by means of expert judgments; reliability with three pilot tests, obtaining a .93 value in Alpha Cronbach; and objectivity, adding questions to pilot tests. The population subject to study was the total of students in process of certification (85), data and analysis of data was made with the SPSS 15 software.

In this article, the complex variable to be analyzed is "The tutor", and it is composed of 33 questions. (Table 1).

\section{Results and Discussion}

\section{Characterization of the participants}

The following is the characterization of the participants which was elaborated through a descriptive study. Based on the questionnaire answers applied to the students, the following profile is understood: a population where most of them are women $(61 \%)$; a high percentage of the interviewed are married $(55 \%)$, although those single are $(44 \%)$ and those with any family legal arrangement (free union $2 \%$ and divorced $2 \%$ ); the predominant age is 39 years, with a slight standard variation of 10.47 , the youngest student was 23 years old and the oldest 63 years old.

As for labor status, $96 \%$ work for an educational institute (84\% public sector and $14 \%$ private sector); therefore, they are students who not only study but also work, most of them (84\%) does not have a study scholarship (only $14 \%$ stated to have one). From those scholarships $6 \%$ are given by Durango Secretary of State Education (SEED) and $4 \%$ by Secretary of Public Education (SEP), $2 \%$ by the National Union (SNTE) and a final $4 \%$ by other institution not specified. Some interviewees are economical supported by their parents (14\%) and $5 \%$ are supported by their work companies. In conclusion most of the students pay their own postgraduate studies.

It is important to highlight that half of the interviewees are school teachers: $44 \%$ elementary level, $11 \%$ kindergarten, $11 \%$ high school, $4 \%$ remote secondary, $1 \%$ kindergarten supervision, $2 \%$ pedagogical technical adviser, $1 \%$ maternal and $3 \%$ did not specify.

The postgraduate studies of the four institutions where this survey was conducted, $59 \%$ is formed of groups of students who graduated at least 10 years ago from bachelor degree. This data indicates the great interest of newer generations to obtain their certification well after graduating from college.

It was requested to the interviewee to indicate their work schedule. 85 different answers were obtained. $39 \%$ of them work around $5: 30$ to $7: 30$ hours a day, $45 \%$ work around $3: 30$ to $5: 30$ hours a day and surprisingly $16 \%$ of the students who took part in this study work 7 or more hours a day. Only the $8 \%$ of the interviewee work 1 to 3 and a half hours a day.

When asked how much time is invested on the thesis research, $60 \%$ stated that from 1 to 5 hours weekly, and $21 \%$ from 6 to 10 hours weekly, $7 \%$ between 11 and 15 hours and the $2 \%$ dedicates 16 to 20 hours and only $5 \%$ dedicate 21 to 25 hours to research.

Last nominal question indicates how many books postgraduate students read yearly. $62 \%$ reads 1 to 5 books yearly, on average the candidate reads 5.04 books with a standard deviation of 6.5 , which indicates that $6 \%$ does not read a single book a year. The most repeated answer was: 2 books.

As a cultural background statement it is important to mention that from 108 countries, UNESCO gives Mexico the one place before the last one on reading levels. On average Mexican read 2.8 books a year, but only $2 \%$ of the population has the reading habit. (Proceso magazine, 2013)

\section{Descriptive statistics}

1) Students perception on the common key traits on tutors which allow them to foster their process of certification.

Next, the results are presented on the descriptive statistics about the perception on the common key traits on tutors which allow them to foster their process of certification. The most significant variables are introduced; they foster the process of certification. 
The general average obtained in the application of the instrument in the Tutor Factor was 8.8. it can be stated that students from the four institutions that participated in this research considered as strengths the following traits:

a) Students consider to be important that the tutor has a high knowledge on the subject matter and on the different contents; thus, he is able to conclude his thesis and obtain the degree. $(X=9.6)(S=1.6)$.

b) Students consider important that there should be empathy between the two parties. $(X=9.2)(S=2.3)$

c) Tutor is accessible to meet when there has not been a previous meeting agreement to receive guidance. $(X=8.9)$ $(S=2.0)$

d) Tutor suggests bibliography from different sources (books, authors) so as to consolidate students' research thesis. $(X=8.8)(S=2.6)$

e) Students are motivated to conclude the research on time. $(X=8.7)(S=2.6)$

f) Students are encouraged to present advances on a written basis. $(X=8.7)(S=2.2)$

Based on these results it is possible to identify the common key traits tutors have which Foster the process of certification, among those are: students consider to be crucial tutor has a high knowledge on the subject matter and on different contents that allow the student to conclude his research. Students value empathy between the tutor and the one being tutored. Students value the fact to meet even if there has not been an agreement to meet. Students also care about the fact that the tutor offers suggestions on bibliography sources to consolidate the research work. Students value the tutor who motivates the postgraduate student to conclude the research thesis on time and also motivates him to present work in advance in written form.

2) From the student's point of view, it is concluded that the common traits on tutors with less value in the process of certification are:

On the other hand there are also common traits, which according to students, do not foster at all the process of certification:

a) Tutor involves students on collaboration with other research groups. $(X=5.4)(S=4.2)$

b) Tutor encourage students to write journals to be published. $(X=5.9)(S=3.9)$

c) Tutor motivates students to have his papers published. $(X=6.5)(S=4.0)$

d) Tutor has explained the nature of the certification process in order to obtain the certification degree. $\quad(X=6.6)$ $(S=4.1)$

e) Tutor offers guidance on the nature of the research and the expected standards. $(X=6.7)(S=3.6)$

f) Tutor has recommended congress talks, collaborations, etc. which Foster the knowledge on the given discipline field. $(X=6.9)(S=3.7)$

g) Tutor keeps frequent contact through scheduled meeting at least once a week. $(X=6.8)(S=3.7)$

Based on the results, data indicate that from student's perception the traits which weaken the process of certification are:

Tutor does not involve students on collaboration with other research groups, does not encourage students to write journals to be published, does not motivates students to have his papers published, has not explained the nature of the certification process in order to obtain the certification degree. Tutor also does not offer guidance on the nature of the research and the expected standards, has not recommended congress talks, collaborations, etc. which Foster the knowledge on the given discipline field, Tutor does not keep frequent contact through scheduled meeting at least once a week.

\section{Conclusions}

Based on the answers to the given questionnaire, the following profile is derived: population is women, mostly $(61 \%)$, predominant age average is 39 years. 55\% are married $96 \%$ of the students work for an educational institution, $84 \%$ on the public sector and $84 \%$ does not hold a scholarship for completing his studies. More than half of the students are teachers to basic level and $44 \%$ are elementary teachers.

An alarming fact is that $62 \%$ stated that reads up to 5 books yearly, the average is 5.04 books a year with a standard error of 6.5 , which indicates that $6 \%$ of the students does not read a single book a year and the most repeated answer was two books a year. According to the results obtained in the characterization of the students, it is conclusive that postgraduate programs and tutoring promote reading which in turn will activate knowledge, motivate intelligence, increase cultural awareness and gives information, new knowledge, good writing skills and consequently ideas, projects, thoughts, argumentation and the building up of the thesis will be much more focused whether it is written or oral. 
One of the purposes of education is to promote the processes of personal growth framed in a cultural group where he belongs. This knowledge will not be produced satisfactorily unless proper and specific assistance is given to the student through the student involvement in international activities, which must be planned and systematic to foster the constructivis $t$ mental awareness. (Díaz-Barriga \& Hernández 2002). Delors, proponed in 1996 one of the most suitable ways to promote universal values to incite Young students to study great books from the past and perpetuate the beautiful traditions.

The master degree programs within the four institutions where this questionnaire was implements, $59 \%$ is conformed by groups of students with less than 10 years after being graduated from bachelor, and this percentage indicates they are interested on improving academically. 39\% of the interviewed students work between $5: 30$ to $7: 30$ hours a day. $60 \%$ indicated that they dedicate around 1 to 5 hours a week to thesis research

Regarding the results in the descriptive statistics about students perception on common tutor traits, it is conclusive that the graduate students considers important that the tutor has a high knowledge on the subject matter and different contents in order that the student is able to conclude his thesis and obtains his degree $(X=9.6)(S=1.6)$; students also consider important that the tutor and the very student share empathy $(X=9.2)(S=2.3)$; Tutor motivates students to conclude their thesis within the established time. $(X=8.7)(S=2.6)$; Student is motivated to present periodically his advances in a written form. $(X=8.7)$ $(S=2.2)$.

On the other hand, it is concluded that the common traits tutors have which weaken the process of certification are: tutor involves students onto collaboration with other research groups. $(X=5.4)(S=4.2)$; Tutor encourage students to write papers to be published. $(X=5.9)(S=3.9)$; Tutor motivates students to have his research published. $(X=6.5)(S=4.0)$, d) Tutor has explained the nature of the process to obtain the degree. $(X=6.6)(S=4.1)$; Tutor gives guidance on the nature of the research and the expected standards. $(X=6.7)(S=3.6)$; Tutor has recommended congress, collaborations, workshops etc. to enhance knowledge related to the subject matter students are researching about. $(X=6.9)(S=3.7)$; Tutor keeps regular contact trough frequent sessions with students at least once every three weeks. $(X=6.8)(S=3.7)$.

Experience revels that students let years go by after concluding their studies and dome of them never take their thesis back to have it concluded; therefore, they do not have the experience to start the procedures to present their thesis and thus graduate and obtain the degree of master. Jaik, "states that the answers or the causes that originate this issue are endless". (2013 p. 40).

Based on this research, it is concluded that in order to increase certifications and thus terminal efficiency, it is necessary to straighten tutors in the Teacher Training Institutions, they are essential to those students who really want to certificate their degree, writers such as Martínez, Laguna, García, Vásquez, \& Rodríguez (2005), state that postgraduate tutors must fulfill with the mission to train the new generations, tutors must train them to undertake relevant, high level academic research and a social commitment which contributes to the solution of social problems, and at the same time, to enhance the national educational system at all levels.

\section{References}

[1] De la Cruz, G., Arceo, D., \& Hernández, A. (2010). La labor tutorial en los estudios de posgrado. Perfles educativos, 32(130), 83-102.

[2] Delors, J. (1996). La Educación Encierra un Tesoro. Unesco

[3] Díaz-Barriga F, \& Hernández G. (2002). Estrategias docentes para un aprendizaje significativo. Una interpretación constructivista. $2^{\text {a }}$. ed.) México: McGraw Hill.

[4] Espinosa, D. (2013). Experiencias tutoriales en el posgrado el Centro de Actualización del Magisterio del estado de Durango. Ra Ximhai, vol. 9, núm. 4, septiembre-diciembre, 2013, pp. 199-212 Universidad Autónoma Indígena de México El Fuerte, México.

[5] Navarro M, Jaik A. \& Barraza A. (2010). Sujetos, prácticas y procesos educativos. Una mirada desde la investigación educativa. Capitulo s/n: Análisis de las variables relacionadas con la eficiencia terminal bajo el modelo del comportamiento organizacional, pp. 37-47 Ed. Red Durango de Investigadores Educativos A.C.

[6] Jaik A. (2013). Competencias investigativas: una mirada a la Educación Superior. Instituto Politécnico Nacional CIIDIR Unidad Durango Primera edición.

[7] Martínez, A., Laguna, J., García, M. , Vásquez, M. \& Rodríguez, R. (2005). Perfil de competencias del tutor de posgrado de la Universidad Nacional Autónoma de México. México: UNAM. 
[8] Revista Proceso. Entre 108 países, México es penúltimo lugar en lectura Revista Proceso.com.mx [internet] http://www.proceso.com.mx/?p=339874 recuperado en abril, 2013.

Table 1. Items on variable "the tutor"

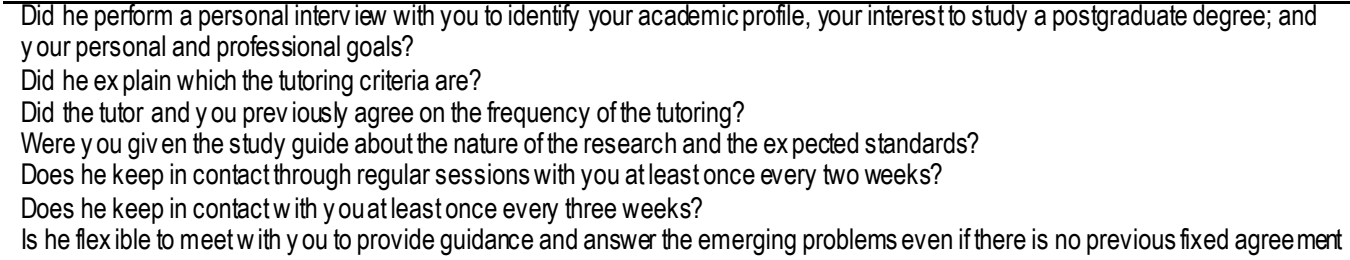
to meet?

Were y ou informed about the institutional facilities av ailable (library, computer labs, etc.)?

Were y ou giv en guidance on ethical and legal aspects concerningyour research?

Does he Foster the application of ethical norms?

Does he provide information necessary on dates and stages of w ork so as to accomplish established deadlines?

Are y ou asked written work and required reports and then are you given back those papers with the proper positive feedback?

Are y ou asked written work and required reports and then are y ou given back those papers at a reasonable time (usually two

weeks after)?

Does he offer guidance on strategies to prepare the thesis?

Does he suggest bibliography in order to consolidate the research?

Are y ou oriented through strategies to dev elop abilities for the correct usage of written language on the thesis elaboration?

Are y ou motiv ated to present periodically your advance orally?

Are y ou motiv ated to present y our advance written?

Do y ou receive guidance on the methodology of the research?

Do y ou receive guidance on the interpretation of the results of the research?

Has he recommended theatrical or practical courses, congress, etc. to strengthen the knowledge in the subjectmatter or related disciplines?

Are y ou motiv ated to $w$ rite research papers to be published?

Are y ou recommended to attend drafting courses on scientific papers?

Are y ou inv olved to collaborate with other research groups?

Has he maintained a sy stematic scheduled on agreements and established activities?

Has he ex plained the process of the final exam to obtain the degree of Master?

Does he motiv ate y ou to conclude your research on the given time?

Does he motiv ate y ou to publish your research?

Do you consider important the existence of empathy betweenyou and the tutor?

Do y ou consider important the existence of communication to a higher lev el between you and your tutor?

Do y ou consider important that the tutor has a high lev el of know ledge to help y ou conclude your thesis and obtain y our degree?

Do y ou consider it is up to y ou solely to conclude the thesis and obtain the mater degree?

Does he treat y ou respectfully?

Source: Own ellaboration. 


\title{
The Insertion of Latin America in the Global Context. A Focused Approach to Regional Economic Development
}

\author{
Luiz César Fernandes da Silva \\ Paulo Reis Mourão
}

School of Economics and Management of the University of Minho

\begin{abstract}
The 90's was a period of significant change for the Latin American economies. Countries experience considerable political and institutional reforms to make the trade and financial openness. The implemented model of economic development shall be based on liberalizing measures in reducing the state's role in the economy and was attributed to the market the lead role of inducing economic system. At the end of the decade, poor results on the economic and social sphere were reflected in several countries and a further review in development policies is now favored. Thus, the ideas of theoretical analysis of the thinking of the Economic Studies Committee to Latin - America (CEPAL) is postulated on the agenda. Based on the Keynesian thought and a historical-structural approach, the production of the institution lies in the analysis of the conjecture and consequences of deregulation and economic and financial liberalization that prevailed. He proposed an approach to regional economic development that would reconcile economic growth with better income distribution, employment and growth with technical progress and social equity. This paper considers, by inserting the Latin American countries in the global integration in the 90s, the ideal of theoretical analysis of the thinking of CEPAL, the socioeconomic situation, as an alternative form of the reforms made in that decade. Therefore, it makes for a bibliographic approach, a reflective analysis highlighting the opinion of the institution.
\end{abstract}

Keywords: CEPAL; Development; Productive processing; Social Equity.

\section{Introduction}

In 1948, there was the emergence of the school of economic thought CEPAL, focused on Latin American structuralism, concerned with economic growth combined with economic and social development. Their emphases fall at the same time, production, society and the observation of different forms of dependencies between the peripheral countries (undeveloped) and central (developed). The spread of this progress occurred differently in the center and the periphery. In advanced countries it spreads to the whole economy, producing the effect of raising the overall productivity of the system, while in the peripheral, modern technologies have been incorporated in the export sectors, focused on the supply of food and raw materials of the central economies (primary-exporting countries). (Prebisch, 1949).

The thematic basis of the institution refers to the analysis of underdevelopment, for, from there, to seek solutions to growth and economic development in the long term, sustainable. For CEPAL, underdevelopment can be synthesized into two basic propositions: the first was that Latin American economies have developed poorly diversified structures and poorly integrated with a dynamic primary export sector, unable to spread technical progress for the rest of the economy, employing the set of hand labor and to allow sustained wage growth real; The second, the rate of incorporation of technical progress and increased productivity would be significantly higher in industrial economies (center) than in economies specializing in commodities (periphery).

However the transfer of productivity gains because of trade did not arise from the center to the periphery, but it was observed the other way - periphery transferred their productivity gains to the center, resulting an increasing disparity between them. This thesis is linked to the economic cycles by the idea of Schumpeter and how the underdeveloped structure of production and the labor of the peripheral countries did not allow these to assimilate the fruit of technical progress market (Fusfeld, 2001). Note that the analysis is to demonstrate that the development in the peripheral countries 
is different from the classical transition that took place in developed countries. Underdeveloped countries are submitted (limited) for the development of other countries and its late participation in global capitalism. Thus, overcoming underdevelopment necessarily involves rupture with external dependence. Without ignoring the general contributions of economic analysis, CEPAL signals to study the specificity of the process of structural and peripheral growth of the countries of Latin-America. That is, it observes that the characteristics and the particular problems of these nations determine specific studies. "One of the most conspicuous deficiencies of general economic theory, from the point of view of the periphery, is its false sense of universality." (Prebisch, 1949, p.4)

With a historical-structural approach and based on Keynesian thinking (Interventionism, defense-growth policies of investment and product critique of Sav's law, emphasis on domestic demand and effective rejection of orthodox theories of inflation and international trade), the CEPAL was characterized as a school of thought specialized in examining the economic and social trends of medium and long-term Latin American countries. Sixty years after its creation, in all the decades the institution postulated his theoretical ideas about the diversity of economic and social problems that occurred on the countries of America - Latin. In the decade of 50, the argument rests on the possibility of changing the productive structures to reduce external dependence of peripheral countries to achieve development. It is necessary to carry out industrialization policies as a way to overcome underdev elopment and poverty. Thus, the government plays an important role in the planning, allocation of resources and protectionist measures to counterbalance productive differences between the center and the periphery. In the 60s, it was understood that the transformations necessary to industrialization correspond to fundamental changes in production structures, as growth in peripheral countries occurred in macroeconomic instability. In the 70s, with increasing concentration of income, the analysis rests on the problem of a locative efficiency due to driving errors of industrial and trade policy. To correct indicate solutions to enhance industrialization and exports as mechanisms to face the difficulties of international integration. Warn of the risk of debt, financing and deliberate trade liberalization. The delicate ${ }^{180}$, proposed policies are on income adjustments, monetary and fiscal. Advocate replacing a recessive adjustment in the balance of payments by an expansive setting for resolution of the external imbalance and the use of economic policies to enable the productive structures could accommodate the necessary reallocation of resources (Bielschowsky, 2000).

A special period of significant change for Latin American economies, occurs in the 90 countries undergo considerable political and institutional reforms to make the trade and financial openness. The implemented model of economic development shall be based on liberalizing measures in reducing the state's role in the economy and was attributed to the market the lead role of inducing economic system. At the end of the decade, poor results on the economic and social sphere were reflected in several countries and a further review in development policies is now favored. Thus, the institution considers its consideration of the conjecture and consequences of deregulation and economic and financial liberalization in force. He proposed an approach to regional economic development that would reconcile economic growth with better income distribution, employment and growth with technical progress and social equity. The "idea-matrix" is the productive transformation with equity. Is related (among others) the discussions on the difficulties for effective and productive social change, ineffective export specialization and external vulnerability to capital movements that are characteristic of the process that period (Moretto and Giacchini, 2006)

\section{The 90 and the position of CEPAL}

Proposals around the transformation of the productive structures of the region conjecturing greater social equity. "Productive Transformation with Equity", or TPE, (1990) was given from the lessons left by the debt crisis of the 80s In the TPE, it has been suggested an updated of the development. Several authors have suggested how these evidences should have harmonized economic growth with better income distribution and the consolidation of democratic regimes. There was also the recognition that the Latin American status has become more dependent on the fluctuations of the global economic order. Thus, economic integration and intra-regional cooperation would be important around specific goals to strengthen international integration, productive articulation and interaction between public and private actors. Beyond,

And the primacy of Neoliberal ideas (market as a promoter of the economy) and the degree of "integration of world economies" the characteristic of the decade, the economic results - Social Latin American countries in the period were bad. The role of the state as an economic and social articulation in the intervention in promoting the public interest, in its various

${ }^{1}$ The "lost decade", the establishment of liberal ideas from the Washington Consensus and the "failure of Key nesians concept". 
areas and at various levels of intensity, combining responsibility or duty, became the background. The strategy adopted in the period, as Batista Jr. (2000) claimed, was a general presumption assumed dogmatically in favor of globalization, trade and financial liberalization, deregulation, reduced role of the state and a prejudice against what was national.

The periphery countries were then subject to adjustment conditions imposed by the debt crisis and these economies were literally captured by the globalization process, running their stabilization programs in accordance with the rules of liberalized financial markets. One must understand that the basic rule of stabilization with financial openness is the creation of an offer of attractive assets that can be taken over by the general movement of globalization. This list included public debt, in short, highly liquid large; shares of companies in the privatization process; bonds and commercial papers of companies and reputable banks (Belluzzo, 2005, our translation)

In this scenario, emerges the possibility of a new revision in policy in order to rethink growth with economic development. Faced with the situation, CEPAL conditioned its approval to a strategy to reduce social inequalities. It directed to the need to enable a policy for achieving a "genuine competitiveness." This policy would be based on technical progress and expansion of existing infrastructure, increase the level and access to education, improved technical training of skilled labor and the creation of a stable macroeconomic environment as opposed to a "spurious" competition, that was integrated to currency devaluations and low wages. The state action should continue this, especially in the service of the economic system efficiency and social justice (Bielschowsky, 2000).

For this author, there is the "neo-structuralism", from the 90 s, as they continue in a way, "the three underdevelopment of the features identified in the '50s."

The "new structuralism" focused then on the policy development, adapting in its speech, a new state position in the economy and an "open" dialogue with the "right" and "left" with regard to the institutional ideological theoretical aspect. In relation to this 'new strategy', Batista Jr. (2000), points out that there was a valuation of the role of the state and of the national issues, which have always been clear to the structuralist tradition (Bielschoswky, 2000a).

\section{Productive transformation with social equity and diversity policies.}

Revenues from TPE aim to change the productive structures in a framework that combines macroeconomic stability, production efficiency, social equity, environmental sustainability and the strengthening of democratic and participatory system. When dealing with these fundamentals, CEPAL draws attention to the fact that most countries in Latin America found difficult to balance economic growth with income distribution. This distortion would be the result of five structural characteristics of the region, which should be considered for the development of a transforming growth strategy; Low level of domestic savings; Low international competitiveness; Weakness of technical progress, Absence of structural breaks in Latin American history, and The continent's economies have never been able to absorb the increase in the economically active population, even in the period of rapid economic growth (1950-1980).

The expansion of the internal market (national and regional) favors a more balanced growth and it is an important basis for technological diffusion by establishing a more positive link between competitiveness and equity. In this respect, for the strengthening of international integration of the production system, the institution proposed a moderate trade liberalization policy consistent with some degree of state intervention, such as the promotion of exports.

The advantages to companies could be provided through joint initiatives by two or more countries. The gains in economies of scale and productive complementarities, also associated with improving the organization of the labor market, credit and education, would lead to reductions in production costs and increased demand. This stemmed from the social integration at the level of each country. Regarding the important factors in regional integration would be the incorporation of technical progress and productive articulation, which includes the addition of income from innovation activities, to reduce trade barriers, promote the standardization of rules and regulations, encourage the creation of centers excellence and reduce research costs (CEPAL, 1994).

International context always had a decisive influence on the performance of the economies of the region. However, there are economic policy measures that may affect differently the short and long-term flows, or productive investments "versus" purely speculative investments. Once capital flows can affect macroeconomic variables, since the negative externalities of international capital markets (such as: frequent cycles of abundance and scarcity of resources) would require countries themselves against the use of these flows. If it does not happen this, could the objectives could be achieved at the expense 
of an imbalance of other important variables, which in turn could affect the instrument itself that it was intended use, is the entry of foreign capital. It would be appropriate for governments to exercise some caution with respect to capital inflows, in order to promote a situation where the aggregate amount and composition are consistent with macroeconomic stability, with investment and growth based on international competitiveness. It would be appropriate for governments to exercise some caution with respect to capital inflows, in order to promote a situation where the aggregate amount and composition are consistent with macroeconomic stability, with investment and growth based on international competitiveness (CEPAL, 1998). For the institution, the degree to which foreign capital flows are functional to a productive transformation strategy with equity depends largely on the characteristics of the domestic financial markets which thus needs an institutional system that supplements this market, for the best use of these flows.

In the economic field, it was confirmed, in the 90s, the urgent need to correct the asymmetry of international integration of the region. It became aware of the importance of maintaining macroeconomic balances short-term and complements them with industry to support the transformation policies. In this conjuncture, productive transformation would require combinations of macroeconomic policies with sectors policies, short and long term, need also occur institutional changes in the search for new forms of interaction between the public official and the private agent.

Macro imbalances reached simultaneously and the production fiscal external beads. Its consequences manifested by foreign exchange shortages, hyperinflation and underutilization of installed capacity. Its macroeconomic strategy for recovery and growth involves three elements: the promotion of exports, a solid fiscal situation and the use of installed capacity idle. For development finance, it would from three main sources: External financing - that one should avoid macroeconomic policy to replace the effort of foreign for domestic savings savings. B) Savings from the public sector looking for alleviating the effects of the fiscal adjustment by creating social programs, and the use of tax instruments to avoid the wasteful consumption of the economic elites, which would explain the insufficient national capacity to build, invest and encourage savings of individuals. C) Saving the private sector - incentives by creating compulsory compensation mechanisms.

Thus, the proposals were based on a readjustment of the tax policy, aiming to increase the public saving that can be used for investment. In trade and exchange policy, a greater openness of the economy as a means of inducing productivity increases and stimulating the adoption of technical progress (the rapid and persistent expansion of exports would be indispensable), a degree of openness due to the availability of foreign exchange and the search the harmonization of tariff protection policies for the exchange rate policy and export promotion policies. In the commercial relationship, complete and adapt the technical infrastructure in priority activities, but delayed; to promote a greater propensity to incorporate technical progress and innovation in the enterprises themselves by granting government incentives to existing enterprises to undertake innovative activities and to support the creation of new, high-tech enterprises for their development in a network of links between the research system and the rest of the technological infrastructure (CEPAL, 1997).

\section{Conclusion}

The transformations based on economic liberalism, in the 90s, for the countries of Latin America-were deep and significant. The idea was to avoid the technological isolation in the era of globalization productive. He thought of a strategy to increase exports via primary and via "niche markets" industrial with the debate in the long run and how to how it should define the state's position in contemporary settings.

Questions of technical progress and the distribution of income are recovered as central points of the thinking of CEPAL. In seeking to understand the requirements that the new international integration model is in terms of modernization of the productive apparatus and in terms of a restructuring of inadequate specialization of economies in the region, focus the analysis on trends and productive and distributive structures, with a view to building authentic competitiveness have.

The accumulation of formations in the region through changes that are caused by the redefinition of the regulatory framework, through the liberalization of markets and the state reform, gain analytical emphasis. The TPE, it must be obtained along with the improvement in the international integration of economies in the region. To improve quantitatively and qualitatively the integration of Latin American economies in the economic globalization process requires simultaneous progress and consistent in a set of policy areas (trade, exchange, productive and financial development) within the framework of a systemic approach. Recognizes that can have a positive influence on the growth process with the liberalizing reforms, provided that they are properly conducted. But the thought of CEPAL requires the recognition that 
America is also justified a set of public policies to support the development, depending on the particular production structures and the organization of markets. It proposes that the objectives of growth and equity are attacked simultaneously and not sequentially.

In the field of public policy, greater understanding must be sought of the ongoing transformation processes, in order to create adequate support for these policies, with ample room for improvement. The new global scenario, along with the new experiences that occurred in Latin America in the 1990s, thus offers a vast field for research with the structuralist methodological approach.

\section{Bibliographic reference}

[1] Batista Jr., PN 2000. The economy as it. Sao Paulo: $3^{\mathrm{a} e d .}$ Publisher Boitempo.

[2] Belluzo, LGM. November 2005 / Apr. 2006. The transformation of the capitalist economy in the postwar period and the source of global imbalances. Magazine Economic Policy in Focus, no. 7 - Section 1.

[3] Bielschowsky, R. Org. 2000. Fifty Years of Thought in ECLAC. Translation Vera Ribeiro. Volume I and II. Rio de Janeiro: Record.

[4] -a-an 2000. Brazilian Economic Thought: Ideological Cycle Development, 4th ed. Rio de Janeiro: Counterpoint.

[5] CEPAL, March, 1990. Transformación productive con fairness: La tarea del desarrollo priority for Latin America and the Caribbean en los años 90. Santiago de Chile.

[6] CEPAL. 1994. El regionalism abierto en America Latina y el Caribe. Thereeconomic integración al servicio de la transformacionproductive con fairness, Santiago. UN Publications, pp. 9 to 19.

[7] CEPAL. 1997. La breach of herfairness. LatinAmerica, theCaribbean Social y la Cumbre ,. Chile Santiago. UN Publications, pages 13-20.

[8] CEPAL. 1998. "Ingreso de capitales and policy implicaciones: recapitulation" in AmericaLatinay el: Policiesfor mejorar itsinsertionintotheworldeconomy, 2nd edition, Santiago de Chile, Fondo de Cultura Economica, págs.427 to 437.

[9] Ferraz, JC; CROCCO, M.ELIAS, LA (organizers). 2003. Economic liberalization and development: models, policies and restrictions. São Paulo: Futura.

[10] FUSFELD. DR 2001. The Age of the Economist. Translation Fabio D. Waltenberg. São Paulo: Saraiva.

[11] Moretto, CF; GIACCHINI. J. 2006. The Emergence of Development Theory to Sustainable Design: Old and New Approaches Towards Sustainable Development.Discussion paper No. 06, Passo Fundo, RS: Brazil.

[12] PEREIRA, LCB2005. The ISEB and ECLAC: To the theory of dependence. Caio Navarro of Toledo, org. (2005). Intellectuals and Politics in Brazil: The experienced ISEB. Rio de Janeiro: Editora Revan: 201-232.

[13] PREBISCH, R.1949. The economic development of Latin America and some of its principais.Escrito problems as introduction to introduction to economic Studio la Latin America, published in, Economic Bulletin of Latin America, vol. VII, no1, Santiago 